\title{
Effect Of Education Media Video On Improve Stroke Prevention Behavior In Continued Age In Wiyurejo Pujon Malang
}

\author{
Indun Muslihati, Yonas Galang Lisandi, Ririn Kasahan, Hendry Agustina Winarko \\ Puskesmas Pujon Batu, Malang, East Java, Indonesia \\ Corresponding author : indunmuslihati74@gmail.com
}

\begin{abstract}
Background: Stroke is a disease caused by one of the pathological processes that affect the blood vessels of the brain. Efforts to reduce mortality from stroke can be done by health education about stroke disease.

Purpose : The purpose of this research is to know the Influence of Media Video Education on the Enhancement of Prevention of Stroke in Elderly in Wiyurejo Village, Pujon Subdistrict, Malang Regency.

Methods : Pre-experimental design research design with one group pre-post test design. Population of all elderly (elderly) between 60-74 years in the Village Wiyurejo District Pujon Malang regency a number of 34 people. The sampling technique used was accidental sampling so that the sample was 32 people. Data analysis Using wilcoxon.

Result : The results showed that stroke prevention behavior before giving video media almost half of educational (46,9\%) respondents have bad behavior. After being given an educational video media showed almost half of them with sufficient behavior (43.8\%).

Conclusion : There is Influence of Educational Video Media to Improving Prevention Behavior of Stroke at Elderly in Wiyurejo Village, Pujon Sub-district, Malang Regency. Looking at the results of the study suggested that the provision of counseling about stroke prevention can be carried out repeatedly in the elderly so as to make efforts in preventing early
\end{abstract}

Keywords : Media Video Education, Behavior, Elderly

Received: February 03, 2018; Revised February 24, 2018; Accepted March 10, 2018

How to Cite: Muslihati, I., Lisandi, Y.G., Kasahan, R., \& Winarko, H.A. (2018). Effect Of Education Media Video On Improve Stroke Prevention Behavior In Continued Age In Wiyurejo Pujon Malang. Journal Of Nursing Practice. 1(2). 12-17 


\section{BACKGROUND}

According to WHO elderly (elderly) is a group of people aged 60 years or older. Globally by 2013 the proportion of the population aged over 60 years is $11.7 \%$ of the world's total population and it is estimated that this number will continue to increase with increasing life expectancy. As the age increases there will be a decrease in the elasticity of the body system. In the elderly generally will also decrease the size of the organs of the body but not the heart. The heart of the elderly will generally grow. This leads to an epidemiological transition from infectious diseases to degenerative diseases that one of them is a stroke (Fatmah, 2010).

A stroke is an acute neurological disorder, caused by a blood circulation to the brain where suddenly (within a few seconds), or precisely (within a few hours) symptoms and signs appear in the focal area of the brain. Stroke is a disease caused by one of the pathological processes that affect the blood vessels of the brain. Stroke disease today tends to increase with a high mortality rate. Stroke is the third leading cause of death after heart disease and cancer (Arief, 2006).

In the World, stroke is estimated to cause 7.5 million deaths or about $12.8 \%$ of total deaths. This accounts for 57 million of disability adjusted life years (DALY). About 25\% of adults in United State suffer from stroke in 2011-2012. There was no difference in prevalence between men and women but prevalence continued to increase by age 5\% 2039 years, $26 \%$ age $40-59$ years, and $59.6 \%$ for age 60 and older (Akin, 2014). The prevalence of stroke in Indonesia is based on the diagnosis of health workers by 7 per 1000 and based on the respondents' answers who have been diagnosed by health workers 12.1 per 1000 (Basic Health Research, 2013). From the result of RISKESDAS of East Java Province in 2014, the prevalence of stroke in East Java was 31.2\% which increased according to age, so that above 55 years exceed 50\%. From the data obtained, it is known that with the increasing age, more and more stroke, so over 65 years get more than $60 \%$, or 6 out of 10 people in East Java (MOH, 2014).

Stroke is closely related to high blood pressure that affects the appearance of damage to blood vessel walls so that blood vessel walls are uneven. As a result, dissolved substances such as cholesterol, calcium and so on will settle on the vessel wall known as the narrowing of blood vessels. If the narrowing of blood vessels occur in a long time, will result in blood supply to the brain is reduced, even stopping the next cause a stroke (Pudiastuti, 2011). The impact of a stroke is the disability and even death depending on the location where the blood supply disorder occurs. Reduced blood supply causes neuron cell death, if lasting up to 72 hours can occur brain damage (Corwin, 2009).

Further complications can be prevented with prompt and precise handling. Preventive efforts and education to the public are also very important to reduce mortality and disability due to stroke. The role of nurses is not only in the prevention of complications and reduce the risk factors for stroke, but also provide information needed elderly in preventing stroke, and encourage families to more effective.dalammelaksanakanperannya.Selain prevention efforts against stroke can be done with health education related to the stroke (Smeltzer \& Bare, 2002).

Based on preliminary study conducted by researchers in Wiyurejo Village, Pujon Subdistrict, Malang Regency, the number of elderly between $60-74$ years is 34 people. The results of interviews about stroke prevention of six elderly, all said that stroke occurs due to hypetensive disease. While the behavior in preventing stroke is not eating fatty foods. 
Based on the above background then the researcher wanted to conduct a study entitled: "Influence of Media Video Education on Improvement of Prevention of Stroke on Elderly in Wiyurejo Village, Pujon Sub-district of Malang Regency".

\section{OBJECTIVE}

Knowing the Influence of Educational Video Media to the Enhancement of Prevention of Stroke in Elderly in Wiyurejo Village, Pujon Sub-district.

\section{METHODS}

The research design used in this research is pre-experimental design with one group prepost test design. This study aims to determine the Effect of Media Video Education on the Enhancement of Prevention of Stroke in Elderly in Wiyurejo Village, Pujon Sub-district, Malang Regency. The population in this study is all elderly (elderly) between 60-74 years in the Village Wiyurejo Pujon District Malang regency a number of 34 people. The sample in this study is partially elderly (elderly) between 60-74 years in the Village Wiyurejo Pujon District Malang regency a number of 32 people. The sampling technique used in this research is accidental sampling. The independent variable in this research is educational video media. Dependent variable in this research is stroke prevention behavior. Statistical test using SPSS version 22.0 computation with wilcoxon formula.

\section{RESULTS}

Table 1. Behavior Prevention of Stroke in Elderly before being given Media Video Education in Wiyurejo Village Pujon Sub-district, Malang Regency

\begin{tabular}{cccc}
\hline No & Behavior & $\mathrm{f}$ & $\%$ \\
\hline 1 & Good & 6 & 18,8 \\
2 & Enough & 11 & 34,3 \\
3 & Lack & 15 & 46,9 \\
& Total & 32 & 100 \\
\hline
\end{tabular}

Based on table 1 above can be seen that almost half (46.9\%) of respondents less in the behavior of stroke prevention and a small (18.8\%) of respondents both in the behavior of stroke prevention.

Table 2. Behavior of Prevention of Stroke in Elderly after being given Media Video Education in Wiyurejo Village, Pujon Sub-district, Malang Regency.

\begin{tabular}{cccc}
\hline No & Behavior & f & $\%$ \\
\hline 1 & Good & 11 & 34,3 \\
2 & Enough & 14 & 43,8 \\
3 & Lack & 7 & 21,9 \\
& Total & 32 & 100
\end{tabular}

Based on table 4.7 above can be seen that almost half $(43.8 \%)$ of respondents with adequate behavior in the behavior of stroke prevention and a small $(21.9 \%)$ of respondents with less behavior in the behavior of stroke prevention

Based on the results of wilcoxon test with the help of SPSS showed $\rho$ value of 0.037 less than $\alpha 0.05$ so it can be concluded there Influence of MediaVideo Education to Enhancement Preventative Behavior of Stroke in Elderly Village in Wiyurejo Sub Pujon Malang Regency. 


\section{DISCUSSION}

\section{Behavior Prevention of Stroke in Elderly before being given Media Video Education} in Wiyurejo Village, Pujon Sub-district, Malang Regency.

Behavior of stroke prevention before giving educational video media showed almost half $(46,9 \%)$ of respondents less in behavior of stroke prevention and a small part $(18,8 \%)$ responder good in behavior of stroke prevention.

Stroke is a disease caused by one of the pathological processes that affect the blood vessels of the brain. Stroke disease today tends to increase with a high mortality rate. Stroke is the third leading cause of death after heart disease and cancer (Arief, 2006). A stroke is an acute neurological disorder, caused by a blood circulation to the brain where suddenly (within a few seconds), or precisely (within a few hours) symptoms and signs appear in the focal area of the brain. Stroke is a disease caused by one of the pathological processes that affect the blood vessels of the brain.

Prior to educating the respondents whose knowledge was made possible by the education of respondents, almost half of them (43.8\%) responded with the last elementary school and a small portion (12.5\%) respondents with the last education of SMA / SMEA. Respondent education influences behavior in acting. In accordance with table 4.9 that of 4 respondents with the last education SMA / SMEA showed all 4 respondents with good behavior. Higher education will affect the knowledge of respondents so as to apply the behaviors that have been obtained from the knowledge. In addition, with the education of respondents will have pengetahaun which increases about stroke.

The respondent's experience can also influence his knowledge in stroke prevention. This is related to information obtained about stroke that most $(59,4 \%)$ of respondents ever got information about stroke and almost half $(40,6 \%)$ of respondents never get information about stroke. Respondents who know in advance about the stroke will understand how to prevent it from being different from respondents who have never received information about stroke prevention.

Prior to educational research conducted by researchers, many of the respondents did not know how to prevent stroke, this is due to lack of information about stroke and prevention so that less knowledge leads to different behaviors. Knowledge is able to change a person's behavior so that lack of knowledge will hinder to perform better behavior.

\section{Behavior of Prevention of Stroke in Elderly after being given Media Video Education in Wiyurejo Village, Pujon Sub-district, Malang Regency}

The behavior of stroke prevention after being given educational video media showed almost half $(43.8 \%)$ of respondents with sufficient behavior in the behavior of stroke prevention and a small (21.9\%) respondents with less behavior in the behavior of stroke prevention

Good health education media is media that able to give information or health messages in accordance with the level of acceptance of the target, so that the target is willing and able to change the behavior in accordance with the message delivered (Notoatmodjo, 2007). Knowledge is the result of "knowing", and this occurs after people make sensations to a particular object. The realm of knowledge according to Bloom (1994) is to sort the thinking skills in accordance with the expected goals. The thinking process describes the stage of thinking that must be mastered in order to be able to apply the theory in action. Knowledge is the ability to mention or re-explain such as defining, compiling lists, naming, declaring, identifying, knowing, mentioning, framing, underlining, describing, matching, choosing. 
Based on table that of 13 respondents who had received information on stroke prevention showed 10 respondents with good behavior, whereas in 19 respondents who have never received information shows only 1 respondent with good behavior. Provision of extension methods caused the respondents to increase their knowledge so that understanding in preventing stroke also increased. This will cause the respondent to continue to find out how prevention of stroke. In addition, the work of respondents can also be connected where a small part $(6.2 \%)$ of respondents as pensioners. Respondents as retirees have a lot of information about strokes from their coworkers so that the information also increases. In contrast to respondents who are only at home which causes a lack of understanding in the application of stroke prevention efforts.

Increased behavior against efforts to prevent a stroke is done well after getting information about how stroke and prevention. Provision of education can increase knowledge from respondents who previously did not know to know and understand so mmapu change behavior by applying in daily.

\section{Influence of Media Video Education on Improvement of Behavior of Prevention of Stroke at Elderly in Wiyurejo Village, Pujon Sub-district, Malang Regency}

Based on the results of wilcoxon test with the help of SPSS showed $\rho$ value of 0.037 less than $\alpha 0.05$ so that it can be concluded there is Influence of Media Video Education to Increase Behavior Prevention of Stroke in Elderly in Village Wiyurejo Sub Pujon Regency of Malang Regency

Several factors that influence health education according to Notoatmodjo (2007) include extension factors, such as lack of preparation, lack of material to be explained, appearance less convincing target, the language used is less understandable by the target, the voice is too small and less able to be heard and the delivery of material counseling is too monotonous so boring. Besides the target factors, such as the level of education is too low so difficult to receive messages conveyed, socioeconomic level is too low so not paying attention to the messages delivered because it is more concerned about the more urgent needs, beliefs and customs that have been embedded so difficult to change, the environmental conditions in which the target residence is unlikely to change behavior.

Respondents who were given counseling using educational methods so that will increase knowledge and can know and understand how the correct stroke prevention. Supported by the results of research that is from 32 respondents before giving education showed 6 respondents with good behavior and 15 respondents with less behavior, after being given education showed 7 respondents with less behavior and 11 respondents with good behavior.

Provision of education such as giving counseling using image media such as video by the researchers is very helpful in efforts to increase knowledge, especially about stroke and handling. This is shown by some of the respondents who asked and were able to answer questions given by researchers. Educational efforts can increase the information obtained so as to change the behavior to be better than before.

\section{CONCLUSION}

Behavior of stroke prevention before giving educational video media showed almost half $(46,9 \%)$ of respondents less and a small part $(18,8 \%)$ responder good in stroke prevention. Behavior of stroke prevention after giving educational video media showed almost half $(43,8 \%)$ of respondent enough and a small part $(21,9 \%)$ respondents with behavior that less in stroke prevention 
Based on the results of t-test test with the help of SPSS showed $\rho$ value of 0.037 less than $\alpha$ 0.05 so it can be concluded there is Influence of Media Video Education to Enhancement Preventative Behavior of Stroke at Elderly Village in Wiyurejo Sub Pujon Malang.

\section{REFERENCES}

Ananta. 2009. Waspadai Gejala Penyakit Mematikan. Yogyakarta: Nuha Medika.

Arief. 2006. Ilmu Penyakit Dalam. Jakarta: Media Austacius

Azizah. 2011.Keperawatan Lanjut Usia. Yogyakarta: Graha Ilmu

Cahyono. 2008. Gaya Hidup Dan Penyakit Modern. Yogyakarta: Kanisius

Corwin. 2009. Pendidikan Kesehatan, Teori dan Aplikasi. Jakarta: Media Press

Depkes RI. 2012. Promosi Kesehatan Dalam Lingkup Keperawatan. Jakarta: Promkes

Depkes RI. 2014. Panduan Pencegahan Stroke Secara Dini. Jakarta: Promkes

Effendy. 2003. Ilmu, Teori dan Filsafat Komunikasi. Bandung : Citra Aditya Bakti

Fatmah. 2010. Penangangan Stroke. Jakarta: Media Austacius

Mansjoer. 2006. Kapita Selekta Kedokteran. Jakarta: Media Austacius

Maryam. 2008. Mengenal Usia Lanjut Dan Perawatannya. Surabaya: Salemba Medika

Noorkasiani. 2009. Kesehatan Usia Lanjut Dengan Pendekatan Asuhan Keperawatan. Surabaya: Salemba Medika

Notoatmodjo. 2007. Promosi Kesehatan Teori Dan Aplikasi. Jakarta: Rineka Cipta

Nugroho. 2008. Gerontik Dan Geriatrik.Jakarta: EGC.

Pudiastuti. 2011. Penyakit Pemicu Stroke. Yogyakarta: Meha Medika

Riset KesehatanDasar.2013. Upaya Penanganan Stroke Secara Dini. Jakarta: Promkes

Smeltzer \& Bare.2002. Fundamental Keperawatan.Jakarta : Penerbit Buku Kedokteran EGC

Syafrudin. 2009. Hubungan Pengetahuan Tentang Stroke dengan Perilaku Terhadap Pencegahan Stroke Di RS Solo. Skripsi. STIKes Wira Husada Solo

Wahyu. 2009. Stroke. Yogyakarta: Bentang Pustaka

Wiwit. 2010. Stroke Dan Penanganannya. Yoyakarta: Kata Hati 